\title{
Bolsonaro's Brazilian Christofascism during the Easter period plagued by Covid-19
}

\author{
Fábio Py ${ }^{1}$ (D)
}

Received: 10 July 2020 / Accepted: 14 September 2020/Published online: 28 September 2020

(C) Springer Nature Switzerland AG 2020

\begin{abstract}
The article highlights the media actions of the president of Brazil, Jair Bolsonaro, in the face of the expansion of the pandemic of the new coronavirus, Covid-19, in Brazil. For this, the Easter week of 2020 was separated when a comparative operation of Bolsonaro with the figure of Jesus Christ, in his social networks - a tip of what we call Brazilian Christofascism - was woven. Thus, precisely in the period of the celebration of the death and resurrection of the Christian Messiah, we sought to connect Bolsonaro with the figure of Jesus, placing him as the country's savior in the posts on his social networks. For this demonstration we assume that each post would be a "scene," which are "politically staged dramatic acts" (Rancière), in this case, media scenes. Therefore, we argue that during the period, the intellectuals of the Bolsonaro government designed seven scenes to readjust the presidential figure to Christianity for its loss of popularity for the public defense of vertical isolation.
\end{abstract}

Keywords Covid and Christianity in Brazil · Bolsonaro government · Bolsonarism · The Easter of Bolsonaro $\cdot$ Christofascism

\section{Introduction}

The present essay aims to discuss the intentional use, by the president of the Republic of Brazil, Jair Messias Bolsonaro, and his "intellectuals" (Gramsci 1982; Py and Pedlowski 2018), of the figure of the Messiah with more direct likeness to the historic narrative of Jesus Christ in the Easter of 2020. The hypothesis goes by a centralized version of political theology being developed precisely in the Easter period of 2020,

Fábio Py

pymurta@gmail.com

1 Faculty of Graduate Program in Social Policies, North Fluminense State University, Rio de Janeiro, Brazil 
due to Bolsonaro's forfeiture of popular support due to his relativizing posture on the positive effects of the quarantine imposed as a response to the Covid-19 pandemic. ${ }^{1}$

Hence, there was a 7\% satisfaction index loss regarding May 2020 in the government's assessment through. Trend changes were due to the way he behaved before the coronavirus pandemic, Covid-19. His stance went on the opposite way compared with the other national leaders (governors and parliamentarians) in the face of the spread of the disease, which is explicited below by "XP Investimentos" graphic.

Evaluation Framework of the Temer and Bolsonaro Governments from May 2010 to April 2020

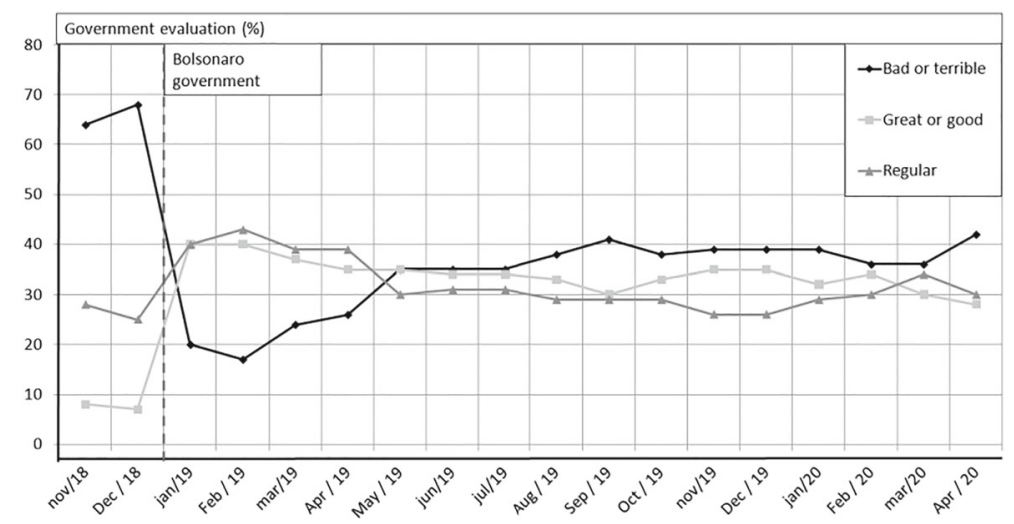

Source XP investments Brasil, April 2020.

Seeking to reverse the popularity loss, the government's "intellectuals" (Gramsci 1982) counter-produced an imaginary discourse, placing him as a "good Christian" (Getsemani 2020), nurtured by messianic appeal, in order to readjust his conservative and fundamentalist Christian social base- - which was being drained its political support. Bolsonaro fed his social base and reinforced with a sort of Manichaeism idealpromoting this "war of the gods" (Lowy 2000) — and doing so he assumes himself as president of the Christians (Bolsonaro 2020a; Bolsonaro 2020b) and brings to bear a simplification of political conflicts, which started to constitute clashes between "good versus evil." In this arrangement, the conflict occurs between those who represent evil, in the caricature of "communists" or "PT members" (leftist political party), and "citizens of good" (Py 2019; Py et al. 2020).

Hence, the present article highlights Bolsonaro's intellectuals mechanism when they bet on the resumption of popular support, as they have already used in July 2019, when "they associate the image of Bolsonaro with the figure of Jesus Christ, in the middle of a serious government crisis" (Py 2019). By doing so, he recounted the figure of the Messiah Jesus Christ into the trajectory of Bolsonaro, a method exercised by the president's intellectual groups, as already written in the article "Bolsonaro's Christofascist Christology" (Py 2019). However, in the week of Easter 2020, this

\footnotetext{
${ }^{1}$ See the data on Bolsonaro's loss of popular support in the early days of the pandemic, https://www. nexojornal.com.br/expresso/2020/04/18/A-popularidade-de-Bolsonaro-na-pandemia-sob-an\%C3\%A1lise e https://www.poder360.com.br/pesquisas/aprovacao-de-bolsonaro-confirma-curva-negativa-28-aprovam-e-42rejeitam/.
} 
resource was reused under the excuse of the religious celebration of Christ's death and resurrection. The allegory of the Christian Easter was the pretext of building the Via Crucis bolsonarista, as a suffering servant who overcame death for the defense of the nation. Addressing the work of Carl Schmitt (1988), we may derive the strength of the Christian appeal by understanding it as a media strategy to keep the authoritarian government.

The political operation of religious use further legitimizes authoritarianism in Brazil, here addressed as "Brazilian Christofascism." The fact constitutes itself as Bolsonarism (Almeida 2019) fabricates an endless "war of the gods" as a strategy to shape a theology of power sustained in the memory of the colonizing European Christ (Dussel 2012). Therefore, in the midst of Easter 2020, under the Covid-19 pandemic context, Bolsonaro government developed an offensive by redesigning an authoritarian Christology of power based on the figure of martyr and Messiah, equating it to the memory of Jesus Christ Easter. An orchestrated action in early April, when a national fast for Palm Sunday (April 5, 2020) was called for, intensified during the week, reaching its peak on Easter Sunday (April 12, 2020). Precisely on the day that Christians celebrate Christ's resurrection and victory over death, in which it was solely compared, by the president, to the stabbing fact he suffered in the 2018 electoral year process.

Consequently, we have set apart seven "orchestrated scenes" (Rancière 2012) by the president's body of intellectuals, collected from the social media network Instagram that culminated in the construction of the Bolsonaro's "Paschal" myth. It is assumed that the concept of "scene" comes from Jacques Rancière's book, La méthode de l'egalite (Rancière 2012), when it indicates that it is "a convergence between theory and practice when capturing the application of the makeup of the elements, the construction of figures, messages, and imagery, printing an exercise, a practice" (Rancière 2012). By saying out these initial elements, it is appropriate to describe in most details what may define, in Brazil, as Brazilian Christofascism-based on the Christofascism of the theologian Solle (1970). Thus, we proceed to describe a little about the term and its effects in Brazil.

\section{Bolsonaro's Brazilian Christofascism}

Featuring the architecture of a Messiah given by Bolsonaro's governmental leadership, I highlight some conceptual elements that I call "Brazilian Christofascism." The Christofascism of Bolsonarist management is promoted in the context of an "authoritarian political theology" (Schmitt 1988), based in the apocalyptic environment of coronavirus, based in the "hatred of democratic plurality" (Rancière 2014). His hatred is voiced in the government's techniques to promote discrimination and, mainly, by discriminatory stances and attitudes towards the "heterodox" sectors (Bolsonaro 2020a; Bolsonaro 2020b). This was seen in the expansion of the coronavirus in Brazil that amplified his habitual anti-democratic appeal of economic breath that justifies the "death policy" ("necropolitica"; Mbembe 2014; Butler 2020)—against the poorest population, the oldest, the diabetics, and the hypertensive patients (Bolsonaro 2020a, 2020b). 
The term "Brazilian Christofascism" is based on the German theologian's own reflections Solle (1970), who created the expression "Christofascism" out of a recollection from German Nazism, especially about Auschwitz, inside her book: Beyond Mere Obedience: Reflections on Christian Ethic for the Future (1970). Sölle's term is concerned with pointing out "the relations of members of the Nationalsozialistische Deutsche Arbeiterpartei (NSDAP - the Nazi party) within Christian churches in the development of the state" (Solle 1970) of German exception. Dorothee Sölle recalls that the Nazi government made use of Christian associations and terminology for its social cohesion, therefore Bolsonaro government as well. ${ }^{2}$

Hitler used Christian idiom placed in his speeches as the "You know the truth and the truth will set you free" (John 8.32) and "created God, man in his image; in the image of God he created him; man and woman created" - in order to defend the traditional views on German Christian family. The Führer made crusades into Christian gatherings (Lutherans, Catholics, and confessionals), relating to pastors and priestsamong some Lutherans pastors stood out Walter Hoff, Rudolf Kittel, and Prospt Ernst Szymanowski, developers of the so-called positive Christianity (Solle 1970). In her book, Solle (1970) points out that white extremists in the USA would have the same "attitude of hatred, prejudice and racism" previously seen in the imperial Nazi regime. When describing fundamentalist groups on American soil, she uses the term "Christofascism" as the action of white supremacist groups in the USA, having very little connection with the formation of the state. She was not concerned with the details of the term, hence highlighting an authoritarian political theology of state trends.

She points to Christofascism as a "blind obedience" when "in relations with the divine of people under authoritarian regimes or within fundamentalist groups" (Solle 1970). Solle (1970) considers the "deepening of the unilateral understanding of Christianity (...) in the Second World War and in the Americans in the context of the extremist violence of Christian fundamentalists." Hence, for her, Christofascism is an authoritarian, arrogant, totalitarian, imperialist theology, characteristic "of the Church in Germany under Nazism, and still alive at the end of the 20th century in the white extremist groups" (Solle 1970) of the USA. With the expression, she considers it to be a "deviation from fundamentalist Christianity in the service of white and patriarchal supremacism, which extends through the spread of fear, punches, misogyny and structural racism" (Solle 1970).

Therefore, affected by the strength of the idea, it is believed that in South America, another type of Christofascism was developed: "the Brazilian" type (Py 2019). It is a mixture of both extremist Christian (fundamentalist) groups as it is an authoritarian, despotical, form of government, such as Bolsonaro's. In this sense, one is more concerned with Bolsonaro's "architecture of government power" (Schmitt 1988), than with the uses given by the German theologian. Sölle does not dwell on "governmental theology" and, even less, on the oppressive theology linked to "coloniality" as Dussel (2012), nor is it inspired by Walter Benjamin's notion of fascism (2012 and 1940). Thus, for Benjamin (2012), the barbarism of authoritarian fascination does not represent a stage of "civilizational regression, but is contained in the very conditions of reproduction of liberal-bourgeois civilization" (Lowy 2000). He understands fascism as

\footnotetext{
${ }^{2}$ Almost all Bolsonaro's speeches cite Christianity by quoting bible verses and Christians greetings (Bolsonaro 2020a; Bolsonaro 2020b).
} 
political machinery for constituting the "state of exception," part of the migration of governmental techniques that dominated the colonies applied years later in Europe.

Fascism is then understood as a "liberation of the destructive forces produced by a bourgeois civilization in crisis in order to keep the process of accumulation in order" (Benjamin 2012). The libertarian philosopher understands that the wonders imposed by the authoritarian government fits together with conservative conceptions of morality, family, and progress, to engender the transformation of the whole national concept into a "state of effective exception" (Gagnebin 2014). Fascist government management involves "disciplining the proletarianized masses, thereby preventing any disturbance to the property regime. It is a matter of allowing such masses to express themselves as masses, as long as the order put is not put in check and that any claims that touch the social structure are contained" (Benjamin 2012).

Another side face of fascism already pointed out is the legacy of coloniality (Benjamin 2012; Dussel 2012; Cesaire 2010). When fascism expanded the warlike dimension of capitalism or, at least, increased the war policy of the state to the heterodox people, to the poor (Gagnebin 2014). It is said that the authoritarian form of Bolsonarism is projected from Christian fundamentalism, by which it simplifies the notion of family in order to promote the elimination of its opponents and/or undesirables, in this case, in the context of Covid-19, those who do not fit into the healthy gap range.

Another trend goes back to the notion of fascism assumed in the material on which Brazilian Christofascism is laid, the "war of the gods", a term by Michael Lowy (2000) re-addressing the book Science as a Vocation by Max Weber (1998). For Lowy (2000), the conflicts over "the polytheism of values and the insoluble conflict of the basic beliefs gods in modern society." Thus, he signals that the term:

first (...) it refers to the conflict in the religious field between radically opposed conceptions of God: from the progressive Christians and that of conservative Christians (both Catholic and Protestant) - a 'coalition of values' (Werkollission another Weberian term) that, in extreme situations such as that of Latin America in the 1980s, it may even be transformed into a civil war. (Lowy 2000)

The author conceives that in Latin American societies, "a real war of gods" takes place, between "various conceptions of gods as a symptom of the social struggles between civil societies and states" (Lowy 2000). We affirm that Bolsonarism operates a "war of the gods," sometimes simplifying and sometimes projecting a fascination of the presidential figure with the messianism of Christianity. This operation is very well constructed by the "body of intellectuals" (Gramsci 1982) that draws the presidential figure as a political Messiah. Whether pointing as a suffering servant, as an anointed one, or as the nation's elect in the context of the Covid-19 pandemic in Brazil.

A last detail cannot be dismissed. Brazilian Christofascism has been influencing the southern territories, as for example, more recently, new authoritarian modulations have been built in Bolivia. We quote the conservative Christian coalition that has the figure of Jeanine Añez, a current interim president, in which in the face of a coup, she has affirmed that the Bolivian "Bible has returned to the palace." We are not going to stop here in this phenomenon; however, we would like to highlight that there is the growth of other authoritarian governments in the South America, evoking Christian discourses, 
for the implementation of ultraliberal agendas, which would be a circuit of "Southern Christofascisms." Now, after the most theoretical signs, let us move on to the description of the "scene" (Rancière 2012) built over at Covid-19 Easter with the figure of Bolsonaro.

\section{The seven scenes of Bolsonaro's Christofascism}

In order to address the construction of Bolsonaro's paschal myth, some "architectural and staged" scenes (Rancière 2012) are analyzed by his intellectuals and the president himself to link him to the figure of Messiah, savior. It is argued that this practice was done aiming an imaginary passage in which it could be seen on social networks, on the president's Instagram (Bolsonaro 2020a). In this arena, he orchestrates videos, photos, and montages that feed daily with a focus on the social media base. Then, the focus of analysis took place between the eve of Palm Sunday, April 5, until Easter Sunday, April 12, 2020.

Effectively, it is believed that each "scene" that will be highlighted "contains a series of intentional intents that aim to capture a time in favor of a social practice" (Rancière 2012) that affect both individually and jointly to build theological content on the figure of the president. With the media operation on the social network, we seek to stylize the image of Bolsonaro as Messiah of the Brazilian nation-a savior also in the context of the Covid-19 pandemic.

\section{The first scene}

The scene was woven (Rancière 2012) in a video, with a little more than 4 min on the YouTube channel of the Getsemani Baptist Church (Igreja Batista Getsêmani 2020), by the title "Outcry and fast for Brazil - April 5th - summoning of the president Jair Messias Bolsonaro" to call the population to \#JejumpeloBrasil, scheduled for April 5, 2020, and posted on the presidential Instagram (Bolsonaro 2020a). ${ }^{3}$ The call video begins with the verse of 2 Chronicles 20, 3: "Jehoshaphat decided to consult the Lord and proclaimed a fast throughout the Kingdom of Judah" (Baptist Church Getsemani 2020).

After the instance, Bolsonaro says "thank you all very much, and those who have faith and believe, Sunday is the day of fasting." With the phrasal sentence, Bolsonaro does not take $10 \mathrm{~s}$, and the rest of the video is arranged with the biblical texts of 2 Chronicles, and the appeal of the evangelical and Catholic leaders listed below: R. R Soares, André Valadão, Rene Toledo, Silas Câmara, Abner Ferreira, Juanribe Palharine, Abe Huber, Mario de Oliveira, Jorge Linhares, Jose Wellington Junior, Marcos Feliciano, Rene Terra Nova, Edir Macedo, Roberto Lucena, Samuel Ferreira, Robson Rodovalho, Valdomiro Santiago, Hernandes Dias Lopes, Luiz Herminio, Santanna, Roberto Brasileiro, Elizete Rodrigues, Marcio Valadão, Guilherme Batista, Valdomiro Ferreira, Humberto Vieira, André Fernandes, Estevão Hernandes, Silas Malafaia, and Samuel Câmara (Igreja Batista Getsemani 2020).

\footnotetext{
3 To provide an idea of the video's political impact, there were 440 thousand hits on YouTube, with 71.7 thousand likes until August 2, 2020.
} 
After the religious leaders sayings, close to the end of the video shooting, he quotes the text of 2 Chronicles 7:14: "If my people, who are called by my name, humble themselves, and pray, and seek my face and convert from bad ways, then I will hear from heaven, and forgive your sins, and heal your land" (Getsemani Baptist Church, 2020). In the making of the shooting production, the objective was to address Christians that Palm Sunday should be made a Fast Day "so God could free Brazil from the plague of Covid-19” (Igreja Batista Getsêmani 2020).

But Palm Sunday is a more strongly Roman Catholic tradition for keeping the Sunday before Easter, recalling Jesus' entry into Jerusalem over the donkey in the rite. At the video, Bolsonaro in a few words summons the Christian population to fast, and then another biblical text appears in response saying: "Do not be afraid, nor be frightened because of this great crowd; because the battle is not yours, but God's" (v.15; Getsemani Baptist Church 2020). Following the sequence of images, with the music and messages in it, it is indicated that it is the king (the ruler) who has to put himself next to God, just like Jeosafá (Getsemani 2020), because the battle would not be for men and women, but for the divine. In the video, some leaders even claim that the president "would have been anointed to take over the nation" (Igreja Batista Getsêmani 2020).

In this first shooting scene, the apostle Valdomiro Santiago summarizes the date as follows: "praying for the nation, praying for the people, praying for the Lord president, that God will sustain him" (Igreja Batista Getsêmani 2020). Another leader, Silas Malafaia, states that "after that, there will be a time of prosperity for Brazil that never was seen, and that all catastrophic predictions are annihilated in the name of Jesus" (Igreja Batista Getsêmani 2020). The video has the thrust to ennoble a devotion, to mobilize Christian sectors to altogether endures the fight against the coronavirus, "to pray and fast so that the plague that plagues the earth" will survive (Getsemani 2020), alongside President Bolsonaro who is the leader, anointed king to rule the nation.

\section{The second scene}

The second scene has taken place on Wednesday, April 8, at the exiting of the Government Headquarters called Palácio da Alvorada (Bolsonaro 2020a). The president received an expedition of Catholics with the image of Our Lady of Fatima. The pilgrims said: "We brought the image of Our Lady of Fatima, because it will free Brazil from communism. Because all of these mistakes are condemned by us, the Roman apostolic Catholics" (Bolsonaro 2020a). In this case, Bolsonaro's supporters build the narrative, linking Nossa Senhora de Fátima to the fight against communism, inducing that a "cultural war" is taking place (Lowy 2000) in Brazil, which puts Catholicism versus communism.

Just in front of Bolsonaro, the leader of the caravan says "that communism is a mistake and puts Catholicism in another direction" (Bolsonaro 2020a). Thus, the leader marks his position of contempt for the social tendencies of Catholicism, such as liberation theology (Lowy 2000). Following the dialog, Bolsonaro continues talking to another member of the caravan:

President, we also ask that Our Lady pour out her blessings on you. There's a lot of burden on you right now. You represent this struggle, it is the struggle against 
communism in our country, that is why we pray for you and we want to pray an Ave Maria asking for her blessings, which will give you strength. What energy to carry Brazil on your shoulders, count on us with our prayers, the victory is ours! (Bolsonaro 2020a)

In the affirmation, the believer follows the line of "cultural war, which slips into the gods" (Lowy 2000), saying that the spiritual battle that is ongoing in Brazil, under Covid-19, resembles struggles that face together with enemies of the nation, that is, "the communists" (Bolsonaro 2020a). And, in the last sentence of the dialog, Catholics in the motorcade indicate the president as a person separated by the divine: "The Lord was raised up by God, he was anointed by God, to be taking our country right now" (Bolsonaro 2020a).

For Roman Catholics, Bolsonaro is considered an "anointed" (Bloch 1995) and also symbolizes the fight against communism in Brazil (Py 2020). Thus, the group of drivers suggest that Bolsonaro has both a political position in which he currently occupies, as well as a religious one, being someone separated by the divine (Bolsonaro 2020a). In the reading of religious, Bolsonaro is a mixture of "someone separated by God" (Bolsonaro 2020a) and the symbol of the struggle against communism, such as "means the figure of Nossa Senhora de Fátima" (Bolsonaro 2020a).

\section{The third scene}

On the very same Wednesday, April 8, 2020, another scene was built by scholars from Bolsonarism (Almeida 2019). Around 8:30 pm, the president made a statement to the nation about the actions he is taking in the face of the pandemic (Bolsonaro 2020b). In the speech scene, he says that the country is experiencing a "unique moment in history, and to be president is to look at the whole and not just the parts" (Bolsonaro 2020b). Thus, he highlights his concerns with the issue of unemployment and isolation due to the Covid-19 pandemic.

However, just before going on with his speech, he indicates "solidarity with families in the face of this war that we are facing" (Bolsonaro 2020b). Even externing solidarity in his speech, he elicits the idea of war that is paramount for his management that in case feeds on conflicts and armed intrigues (Py 2020). He affirms his responsibility to decide the "destiny of the nation in an outbound way, using the team of ministers" (Bolsonaro 2020b) that he has chosen. However, he is moved by the authoritarian moto when he says: "everyone (ministers) must be in tune with me" (Bolsonaro 2020b). Bolsonaro demonstrates his centralized management tendency, making clear the problems of conducting policies that he had been developing with his former Brazilian Minister of Health, Luiz Henrique Mandetta.

The former minister was being controversial, insisting on horizontal isolation while the president affirmed his preference for vertical isolation, that is, only for the elderly (Bolsonaro 2020b). Without mentioning names in the speech, he stresses that the minister should be in tune with him, that is, assuming isolation only for the older age group of the population (Bolsonaro 2020b). Since the very beginning of the coronavirus pandemic in Brazil, Bolsonaro has contradicted the sayings of the World Health Organization (WHO) regarding the option for isolation (Py 2020). The president justified his reasoning by building a dangerous eugenic dichotomy (Butler 2020), like 
this: "two problems to solve: the virus and unemployment." For him, these two issues should be dealt with simultaneously (Bolsonaro 2020b), that is, the workers, although in pandemic scenario, should leave home and expose themselves to contamination, which may increase the deaths between him and his family (Bolsonaro 2020b).

Under the false dichotomy "the virus or unemployment" (Bolsonaro 2020b), he exposes his necropolitical stance of "delivering parts of the population to death" (Mbembe 2014). At the end of the speech, as a Christofascist governor, he returns to the Christian tone: "I want to deliver a much better country that you received from our successor. Let us follow John 8.32: And you will know the truth, and the truth will set you free." Now, after building his speech based on the eugenic dichotomy of "the virus or unemployment", Bolsonaro (2020b) clings to the Christian covering speech to sensitize his Catholic and Evangelical social base.

He quotes his own sayings since 2018 elections (Py 2019; Py 2020), seeking to fill the political process with biblical colors, in addition to insisting on building a Christian government contrary to the other religions that make up the territory (Py 2019). In the last words of the video, he says "I wish you all a Good Friday of reflection and a happy Easter Sunday! God bless our Brazil!". Thus, at the end of the scene, he indicates to know the religious temporality of Easter week; therefore, with this, he aims to make himself a "good Christian" (Py 2020).

\section{The fourth scene}

Passing the "makeup scenes" (Rancière 2012) on Wednesday (Bolsonaro 2020a; Bolsonaro 2020b), on April 8, 2020, the president was silent on social networks almost every Thursday without speaking. He remained silent precisely on Passion Friday, reaffirming that he is familiar with the Christian calendar, when it is a "day of silence related, above all to contrition" (Boff 1972). Passion Friday is a specific time in Christianity that "symbolizes the day of Christ's death, so it is a day for reflection, for the evaluation of each religious" (Boff 1972). Even so, it is common for each religious person, at the end of the day, to pronounce himself in "a tone of assessment in relation to the divinity, such as a public declaration of faith before the symbol of the day of death" (Boff 1972) of his divinity.

Good Friday is a temporal mark in worldly Christianity, symbolizing the day of death of the saving Messiah Jesus Christ. In this context, the president posted, on his profile on social networks, another scene: a biblical text and the image of Jesus crucified (Fig. 1; Bolsonaro 2020a). After the day of silence, assuming the process of reflection and evaluation indicated in the Christian tradition, Bolsonaro posted the fourth media "scenic scene" in Easter week, in the early evening. He posted a strong image for Christianity, with Jesus Christ crucified on the cross (Bolsonaro 2020a).

Alongside the expressive image, the architect attached the fragment of 1 Peter 2:24: "He himself carried our sins on the tree in his body, so that we died for sins and lived for justice, for your wounds you have been cured" (Bolsonaro 2020a). Now, by that, Bolsonaro and his body of intellectuals show that they know other biblical verses, not only the one so quoted John 8:32. The verse of 1 Peter 2:24 deals with the question of the mystery of the resurrection. An important verse in which he highlights the idea of "salvation" from Christ (Boff 1972). The scholars of Bolsonarism (Gramsci 1982; Almeida 2019) make up with the verse of Paul, the central apostle of Christianity. This 


\section{[5

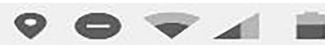 \\ (D) Instagram

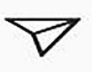 \\ jairmessiasbolsonaro \\ $\vdots$}

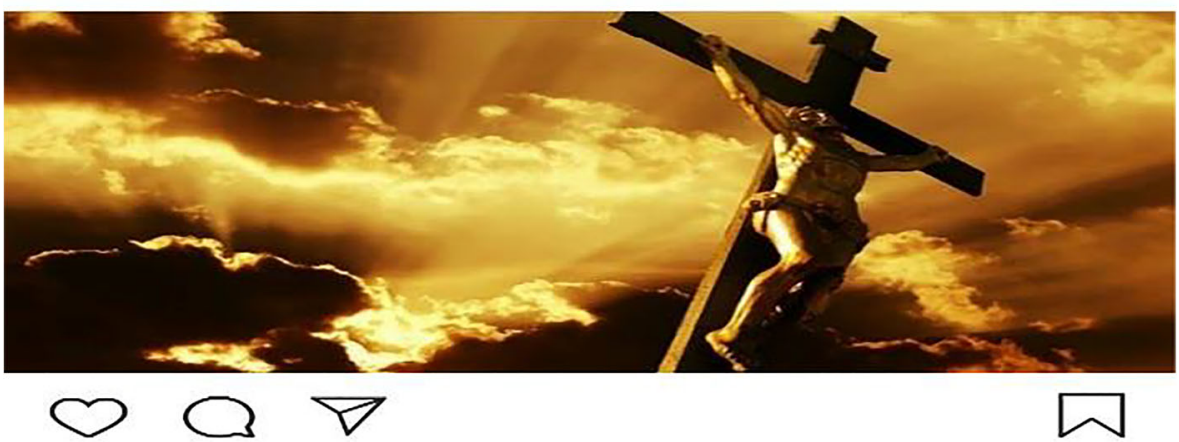

(2) Curtido por michellebolsonaros 2 e outras pessoas

jairmessiasbolsonaro "Ele mesmo levou em seu corpo os nossos pecados sobre o madelro, a fim de que morrêssemos para os pecados e vivêssemos para a justiça; por suas feridas vocês foram curados." 1 Pedro 2:24 - A todos uma Sexta-feira Santa de reflexão. Que Deus nos abençoe!

Ver todos os 7.845 comentários gcasagrande Amém 새.
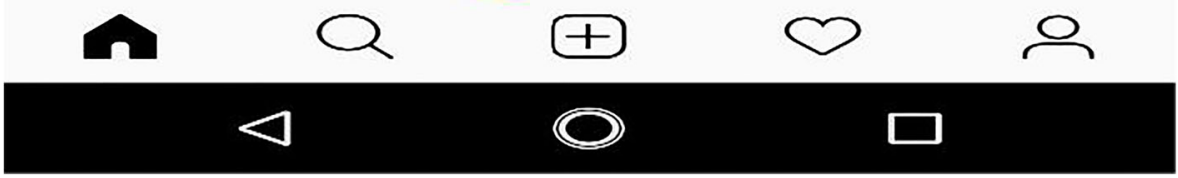

Fig. 1 Jesus Christ crucified and the theology of salvation

verse is written on the walls of several churches in Brazil (Mendonça 2008), emphasizing the importance of "the coming of Christ on earth" (Boff 1972). With the presidential orchestration, he points out that he knows the meaning of Jesus' attitude in the death of the cross. In this sense, Bolsonaro demonstrates that as a "good Christian" (Py 2019), he knows details about the "history of Christian salvation" (Boff 1972), connecting directly with "his described Catholic and Evangelical conversational audience" (Almeida 2019).

\section{The fifth scene}

After the reflective scene, on Good Friday, on Saturday 11th, at night time, he posted a dramatized video (Rancière 2012; Bolsonaro 2020a), telling his story since he took the stab in the electoral process. In the video, he builds his life story from the moment of the stab, in his speech at the Thanksgiving service promoted by the Evangelical Parliamentary Front (Frente Parlamentar Evangélica), on December 17, 2019, at 
Planalto Palace (Bolsonaro 2020a). In an emotional bias, he talks about the stabbing drama he suffered like this "in the most difficult moment of my life, I just asked God not to leave my seven-year-old daughter an orphan. The rest with friends, with real Brazilians, and with God at heart, we will overcome obstacles" (Bolsonaro 2020a).

The video commences assuming the condition of a suffering servant, one who fights to live and to defend the Brazilian nation. The suffering servant tradition has broad bases in the messianism of the biblical traditions of the Hebrew Bible, which deals with the "suffering servant" (in the book of the prophet Isaiah). They who speak of the "suffering servant, a Messiah who in the middle of his mission will be spat out, cut, bruised, who takes the people's pains. The Messiah passes through the world to suffer, in order to rescue the people, save them from the bad ways" (Schwantes 2008).

From the Jewish background, the Christian mentality is arranged, which internalizes the idea of suffering, struggling Messiah, who suffers to "conquer the world and save humanity" (Schwantes 2008). For Milton Schwantes, Christian messianic salvation "necessarily goes through the process of struggles, suffering" (2008). So, for Bolsonaro's theological intellectuals, linked to Christian fundamentalism, Bolsonaro's struggle was won by the suffering, grapple, not to "leave his daughter" (Bolsonaro, 2020) orphan. By that, Bolsonaro reinforces the value of being a father, therefore prioritizing the family, as a universal value for conservative evangelical movements (Almeida 2019).

Bolsonaro affirms that the strength to overcome the attack he has suffered would come from the family or, rather, from his idealization of the Christian family. After summoning his family, he says that "with friends", and also, "with real Brazilians, with God inside the heart" (Bolsonaro 2020a), that he was sure he would overcome everything. Thus, this political Messiah reissues the patriotism of the Military Dictatorship, surrounding himself with people who have God - therefore, those who are not in this program are outside their idealization of nation. In that order, directly, he quotes the updated ideas for his governance of "family, homeland and god" (Fico 2004), which give strength and confidence to "revive" (Bolsonaro 2020a). In part, it turns to the religious tone, related to the family appeal, the patriotic appeal, and the "good Christian" appeal in the face of the martyrdom that passed during the elections (Py 2019).

Following in the "blended scene" (Rancière 2012), by video excerpts, he speaks with the verses of the gospel music in the background. The lyrics of the song appealingly say "story of my life, I fought, I suffered, there were times I got it right, others I missed, life is a journey of love and suffering, and the Lord accompanied me all the time. He was there when the world came crashing down on me. Many said it was the end, I struggled with my faith. Through the valley of the shadow of death, the Lord made me stronger and that is the story of life. I fought, I suffered" (Bolsonaro 2020b).

The song follows what Bolsonaro said of his "reviving, of having come out of death" (Bolsonaro 2020b), lumping Bolsonaro's trajectory, which is shot in the video at the moment of the stab, going through his recovery at the hospital, the prayers and election (Bolsonaro 2020b). When he reached the end, he showed himself as an exemplary Christian figure in the church, praying and kneeling (figs. 2 and 3). 


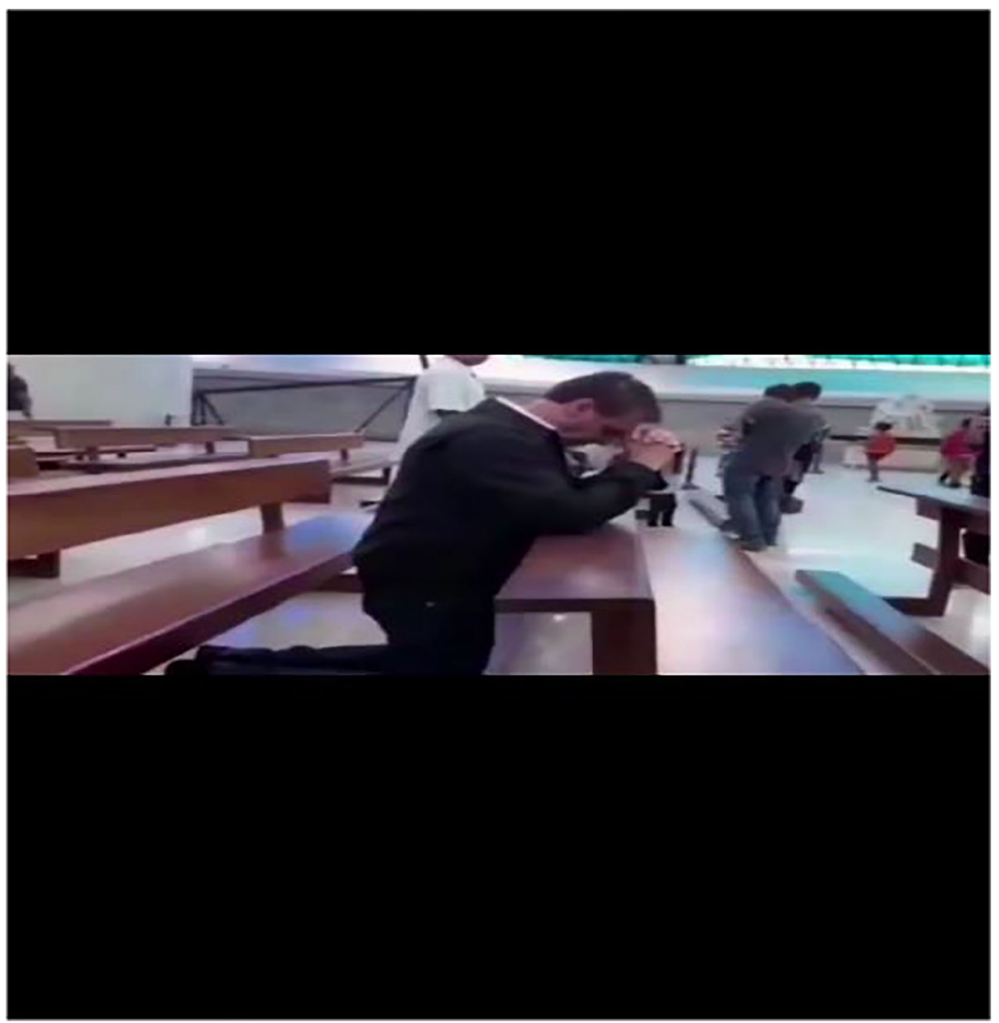

Fig. 2 Bolsonaro praying in the Church (Py 2019)

Thus, his path begins to be drawn, not only as a "good Christian," but as a suffering servant and political Messiah, his victory is expressed "by the miracle of the presidential sash" (Bolsonaro 2020b; Py 2020). In the video, he says that it was only possible because "God preserved his life" (Bolsonaro 2020b). Therefore, due to this ordeal, I would be sent by God to Brazil, pointed in the text: "I lay down and slept. I woke up because the Lord supported me" (Psalm 3:5). Therefore, with this fifth scene, in the middle of Hallelujah Saturday, Bolsonaro and his intellectuals present him both as a "good Christian" (who goes to church, defends the Christian family and the homeland), who begins to draw himself as a leader who has gone through this to be sent, anointed by God to save the nation in the context of Covid-19 (Py 2019).

Amidst Hallelujah Saturday, or Holy Saturday, as the temporality of "a time when the hope of Jesus' resurrection is celebrated, when after the crucifixion, the disciples project the possibility of resurrection, of reviving" (Boff 1972), begins to be appointed as the nation's political-religious Messiah. Therefore, in this forced exercise of Bolsonarist intelligence (Gramsci 1982), emerging from the Christian tradition, it shows Bolsonaro as someone that Jesus is aside, caring for and doing miracles and wonders and so, as shown in figure (3), of himself being surgically operated with Jesus by his side. And for this same reason, a political Messiah is made to take care of the nation in these complex and pandemic days. 


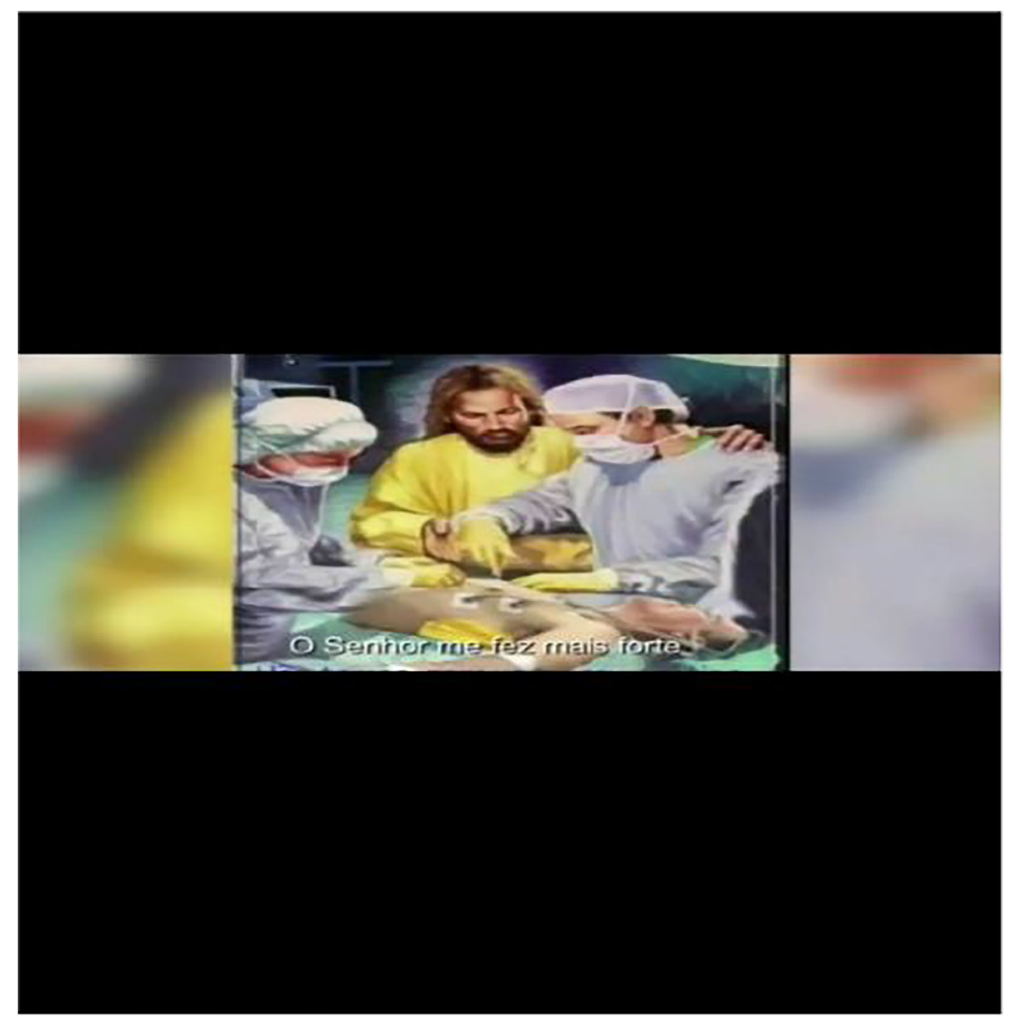

Fig. 3 Bolsonaro proetted by Jesus in the medical operation

\section{A sixth scene}

On this further occasion, the sixth scene was made up in Bolsonaro's post on the social network during Easter Sunday morning, April 4, 2020 (Fig. 4; Bolsonaro 2020a). In the morning of Easter Sunday, when the Christian celebration that marks the "resurrection of Jesus Christ, Messiah savior, his victory over the Roman death empire" opens (Boff 1972), Bolsonaro makes up a text that deals with of the "nature of Christ", that is, within the Christian tradition that marks the debate of "Jesus, whether he was man or God, or both" (Boff 1972).

He makes use of the biblical text in order to publicly demonstrate his faith (Mendonça 2008), based on the classic text of the Gospel of John: "Because God loved the world in such a way that he gave his only begotten son, so that everyone who in him he believes does not perish, but has eternal life" (John 3:16). Again, it evokes the Gospel of John, the most important book of the Bible for the expansion of Christianity.

John is the most famous Gospel among Brazilian Christians and has its words and fragments "widely used by missionaries and fundamentalist pastors in their pastoral practice in the history of Brazil" (Mendonça 2008; and also Py 2020; Zwetsch 2015). Therefore, the Gospel of John is the scene of a variation of "theological reasoning for the propagation of the Evangelical faith from its message more linked to the Greek empire, then to Hellenism" (Mendonça 2008). 


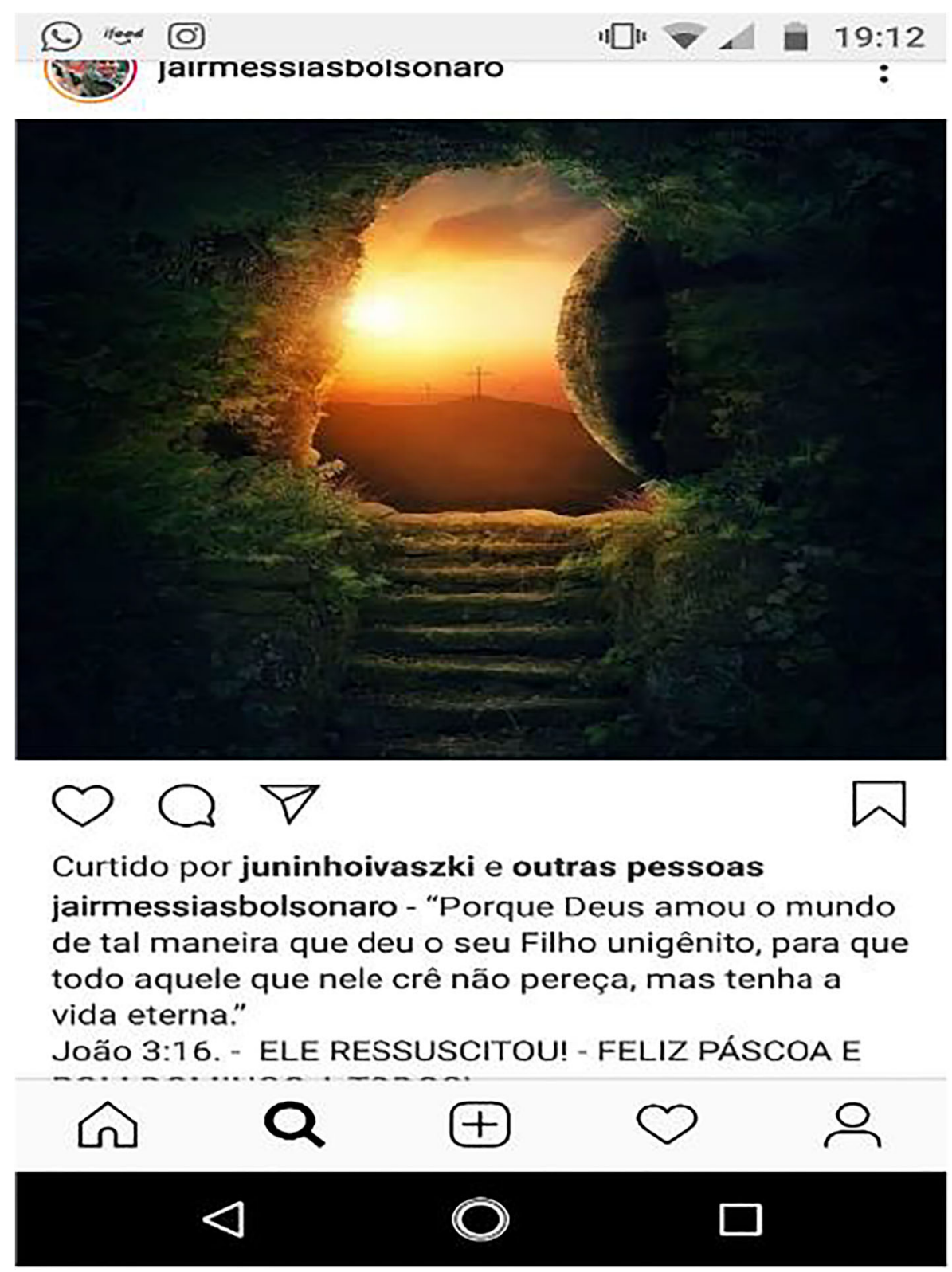

Fig. 4 Image about the resurrection of Jesus (Bolsonaro 2020a)

By the "scene composition" or configuration (Rancière 2012) in the Easter post (Bolsonaro 2020a), he affirms the key theme of the day: "He is risen." Again, he demonstrates that he has intimacy with the Holy Scriptures and is thus in tune with the majority tendency of Brazilian Christianity. This is important to be addressed: with the set of posts, Bolsonaro is drawn as an authentic Christian of the great evangelical corporations, and his intellectuals (Gramsci 1982) operate this makeup in a very well treated manner (Py 2020). 
With this set of sequential scenes, it aims to demonstrate that the president knows a range of biblical texts and Christian themes, not only the so-called "you know the truth and the truth will set you free." At the same time, the scene indicates that he is aware of the "Christian salvation theology expressed in the book of John" (Zwetsch 2008) and the theological discussion on the "nature of Christ" based on this Gospel (Mendonça 2008). Through this scene, he highlights his knowledge of more elements of Christianity for those who doubt his adherence to religion.

\section{The seventh scene}

As the second scene, built on Easter Sunday, has taken place in the afternoon, at the meeting promoted on the Internet (Tvbrasilgov 2020) with the leaders of the great Christian structures such as R. R Soares, André Valadão, Eshylla Santos, Father Reginaldo Manzontti, Marco Feliciano, Luiz Hermínio, Bishop Eduardo Bravo, Josué Valandro Junior, Dom Fernando Figueiredo, Rabbi Leib Rojtenberg, Apostle Estevan Hernandes, Bishop Sonia Hernandes, Bishop Rodovalho, Rene Terra Nova, Adriana Arydes, Silas Malafaia, Bishop Abner Ferreira, Rev. Teófilo Hayashi, Samuel Câmara, Missionary RR. Soares, and JB Carvalho (Tvbrasilgov 2020). At the beginning of the last scene of Easter week, Bolsonaro opens the video saying "the forty leaders who will transmit a word of faith and hope, and of the meaning of Easter" (Tvbrasilgov 2020).

It strengthens the number and importance of leaders in the religious environment and also reports that a pastor sent him a video and that video was the "most important video he was sending" (Tvbrasilgov 2020). He says that the pastor recorded the video from Israel, indicating that "Jesus' tomb was empty, saying that he was resurrected and went to heaven" (Tvbrasilgov 2020). Now, with his usual difficulties in articulation, he signals that he knows a little more about the story of Jesus from the Gospels, who was searched for in the tomb and was not found (Boff 1972).

The president then has taken the opportunity to say that the event "will comfort everyone who is connected to our social media to hear words, that really, increasingly show us who we are, each one of us, and we know that we are all equal, no exception. And, that we must do good, so that we can dream about what we all want: peace" (Tvbrasilgov 2020). In this part, Bolsonaro calls for everyone to "be equal: without exception," returning to the idea that before God, everyone would be equal and that everyone should "do good" (Tvbrasilgov 2020).

Then relates two important elements in Christian social unity in Brazil: "the practice of good" and the struggle for "peace" (Tvbrasilgov 2020). After this initial speech, he gives the room to the religious, and, at the end of the video, he resumes the word (Tvbrasilgov 2020). With this speech, he says that he had already gone to the Saturday night video scene: about the stab he suffered at the end of 2018. Compare the attack to Jesus Christ's final trajectory: "I confess that today was a special day for me, since today there is talk of resurrection. I didn't die, but I was there on the edge of death" (Tvbrasilgov 2020).

In this video, in a more acute way, he points out the relationship of his trajectory with the person of Jesus Christ, affirming that it was a miracle to have survived and resurrected to win the elections (Tvbrasilgov 2020). For this reason, he puts himself in the place of the country's "savior." He justifies this by stating that he "did not have a profile of reaching the presidency." Bolsonaro hints that this was part of the miracle 
performed by the divine in his life. As he says: he left "(almost) death" (Tvbrasilgov 2020) for the mission of the presidency of the Republic.

By this practice, he calls himself as "God's chosen" (Tvbrasilgov 2020). For this reason, he has the task of taking care of the country against the chaos the opositors are trying to build by the coronavirus account. Hence, it is praised that "the responsibility is very great, the carrying cross very heavy, with millions of people on my side, who have a green and yellow heart, who believe in God, I believe that we can overcome obstacles" (Tvbrasilgov 2020). He extols patriotism by linking himself to the metaphor of Jesus' crucifixion, with the expression "the cross is very heavy." Again, he defends his thesis of identification with Christ to be recognized as the nation's Messiah.

By the video's ending, he says again about the quarantine issue: "Since the beginning, forty days ago we have had two very serious problems, the virus and unemployment. Forty days the commencing of the virus' end, but the issue of unemployment is hitting hard, but we must hit hard on these two things. Obviously we always fight, we believe in God above all, we will overcome obstacles" (Bolsonaro $2020 \mathrm{~b})$. And, again in the reasoning of the "virus or unemployment", follows what Butler (2020) emphasizes as "an eugenic logic", justified by the government's ultraliberal economist emphasis.

Hence, that so-called political "Messiah" admits the "death of the poor, the weakest" (Butler 2020), placing the inevitability measureness in the face of the coronavirus pandemic disaster in Brazil (Tvbrasilgov 2020). What it indicates is something serious, when in the middle of the event with Christian leaders, it takes on a tone of Christian appeal, in order to be able to mobilize even more its message as a political Christ of the nation for the religious sector.

\section{Conclusion}

As pointed out during the Covid-19 pandemic period, Bolsonarism (Almeida 2019) broadcasts its discourse with messianic tones of political salvation in the country. It promotes such an operation "building scenes and hermeneutics" (Rancière 2012) that make explicit an authoritarian political theology (Schmitt 1988), reverberating contempt for the older population, with chronic health problems in the face of the possibility of death. It does this in order to recover its social base, building a false dichotomy between the social chaos of the quarantine and the unemployment that can plague the country.

As listed in the article, during the temporality of Easter 2020, he wove a strategy of investing heavily in the Christian and Messiah appeal, giving varied and "public evidence of being a good Christian" (Py 2019): He showed to have knowledge of history of Christianity, the Bible, and mainly key biblical fragments. And with that, he painted himself as a Christian Messiah to mobilize his conservative religious base.

Therefore, Bolsonarism underlines a "biblical war" (Py 2020), fought within the Brazilian state, spreading biblical verses as an easy and "holy" way of communicating with Christian fundamentalism. This "biblical war" driven by Bolsonaro is a bridge of direct dialog with fundamentalism, at the same time that it surrounds it with a despotic political theology, carried by an authoritarian messianism, which sacrifices the popular strata. Bolsonaro's political intention is to promote, with biblical discourse, an attempt 
to relativize quarantine, putting at risk parts of the population "that can be discarded, killed" (Mbembe 2014).

When he draws his messianic authority by relativizing quarantine (or saying that the virus has passed), he comes close to the ideas of the typical social eugenics so operated in the past by fascist governments. For this reason, Bolsonarism must account for the thousands of deaths that are already accounted for in the Brazilian territory by victims of Covid-19.

\section{References}

Almeida R (2019) Bolsonaro presidente: conservadorismo, evangelicalismo e a crise brasileira. Novos Estudos Cebrap. https://www.scielo.br/scielo.php?script=sci_arttext\&pid=S0101-33002019000100010. Accessed 14 Jun 2020

Benjamin W (2012) Benjamin e a obra de arte. Contraponto, Rio de Janeiro

Boff L (1972) Jesus Cristo Libertador. Petrópolis, Vozes

Bolsonaro JM (2020a) Instagram. https://instagram.com/jairmessiasbolsonaro. Accessed 17 Jun 2020

Bolsonaro JM (2020b) Pronunciamento do presidente da Republica, Jair Bolsonaro (08/04/2020). Youtube, 8 de abril de 2020. https://www.youtube.com/watch?v=x04OKkxT2Tc. Accessed 17 Jun 2020

Butler J (2020) Capitalism has its limits, IHU. http://www.ihu.unisinos.br/78-noticias/597520-judith-butlersobre-a-covid-19-ocapitalismo-tem-seus-limites

Dussel E (2012) Descolonização epistemológica da teologia. Concilium, n 350

Gagnebin JM (2014) Limiar, Aura e Rememoração. Editora, São Paulo, p 34

Gramsci A (1982) Os intelectuais e a organização da cultura. Civilização Brasileira, Rio de Janeiro

Igreja Batista Getsêmani (2020) Clamor e jejum pelo Brasil - 05 abril - Convocação do presidente Jair Messias Bolsonaro. You Tube, https://www.youtube.com/watch?v=MV7vR1ZX19Q. Accessed 20 Jun 2020

Lowy M (2000) A guerra dos deuses. Petrópolis, Vozes

Mbembe A (2014) Crítica da razão negra. São Paulo, Antigona

Mendonça AG (2008) O Celeste Porvir: a Inserção do Protestantismo no Brasil. São Paulo, EDUSP

Py F (2019) A cristologia cristofascista de Jair Bolsonaro. Carta Maior, São Paulo. https://www.cartacapital. com.br/opiniao/a-cristologia-cristofascista-de-jair-bolsonaro/. Accessed 14 Jun 2020

Py F (2020) Pandemia cristofascista. São Paulo, Recriar

Py F, Pedlowski M (2018) Atuação de religiosos luteranos nos movimentos sociais rurais no Brasil. Tempo 24(2):233-252. https://www.scielo.br/scielo.php?script=sci_arttext\&pid=S1413-77042018000200233. Accessed 20 Jun 2020

Py F, Shiota R, Pozzmozer M (2020) Evangélicos e governo Bolsonaro: aliança nos tempos de Covid-19. Confluências, v.22, n.2, https://periodicos.uff.br/confluencias/article/view/43024. Accessed 13 Jun 2020

Rancière J (2012) La méthode de l'égalité. Bayard, Montrouge

Rancière J (2014) Ódio a democracia. Boitempo Editorial, São Paulo

Schmitt C (1988) Théologie politique. Gallimard, Paris

Schwantes M (2008) Breve história de Israel, São Leopoldo, Oikos

Solle D (1970) Beyond mere obedience: reflections on a Christian ethic for the future. Augsburg Publishing House, Minneapolis

Tvbrasilgov (2020) Celebração de Pascoa no Palácio da Alvorada. Youtube, https:/www.youtube.com/ watch?v=yoULwuldiHw. Accessed 13 Jun 2020

Weber M (1998) A ciência como vocação. São Paulo, Cultix

Zwetsch RE (2015) Missão como com-paixão. Por uma teologia da missão em perspectiva latino-americana. São Leopoldo, Sinodal

Publisher's Note Springer Nature remains neutral with regard to jurisdictional claims in published maps and institutional affiliations. 